\title{
Faktor-Faktor Penyebab Rendahnya Penggunaan Hak Kekayaan Intelektual di Kalangan Usaha Kecil Menengah Batik
}

\author{
V. Selvie Sinaga \\ Fakultas Hukum Universitas Katolik Indonesia Atma Jaya \\ Jl. Sudirman Kav. 51, Jakarta Selatan \\ valerie.selvie@atmajaya.ac.id
}

\begin{abstract}
Ideally, the Intellectual Property Rights should not only beof the property of major industries but should also be of the small-medium industries' property. In fact, there are only few of the small-medium scale industries in Indonesia which utilize the intellectual property rights in their business activities. The problems which would be studied in this research is the factors serving as the challenges for the smallmedium batik industries in Pekalongan and Yogyakarta in using intellectual property rights in their businesses. The method used in this research was empirical approach in form of primary data obtained from the interviews with the representatives of related government institutions and the employers of 14 small-medium scale batik enterprises in Pekalongan and Yogyakarta. This study concludes that in addition to the fact that not all intellectual property rights branches are relevant to batik industries, the batik industry employers both in Pekalongan and Yogyakarta are reluctant to use intellectual property rights due to the complicated, time-consuming, and expensive registration process and the weak law reinforcement related to intellectual property rights violations in Indonesia.
\end{abstract}

Key words : Intellectual property rights, small-medium enterprise, batik.

\begin{abstract}
Abstrak
Idealnya, perlindungan HKI tidak hanya dimanfaatkan oleh usaha besar, tetapi juga usaha kecil menengah (UKM). Namun, dalam kenyataannya, masih sedikit UKM di Indonesia yang menggunakan HKI dalam aktivitas usahanya. Permasalahan yang dikaji dalam penelitian ini adalah faktor-faktor apa yang menjadi tantangan bagi UKM batik untuk menggunakan HKI dalam usaha mereka khususnya di Pekalongan dan Yogyakarta. Metode penelitian ini menggunakan pendekatan empiris yang berupa data primer yang diperoleh dari wawancara dengan wakil dari instansi pemerintah terkait dan 14 pengusaha UKM Batik di Pekalongan dan Yogyakarta. Penelitian menyimpulkan bahwa selain tidak semua cabang HKI relevan dengan industri batik, pengusaha UKM Batik di Pekalongan dan Yogyakarta enggan menggunakan HKI karena sistem pendaftaran HKI yang rumit, lama dan dirasa mahal serta lemahnya penegakan HKI di Indonesia.
\end{abstract}

Kata kunci: Hak Kekayaan Intelektual, Usaha Kecil Menengah, Batik. 


\section{Pendahuluan}

Sejak menyatakan diri ikut serta dalam organisasi perdagangan dunia, World Trade Organization (WTO) di 1994, isu hak kekayaan intelektual (HKI) mendapat perhatian lebih dari publik di Indonesia. Perhatian tersebut memuncak ketika pemerintah Indonesia mengeluarkan serangkaian undang-undang (UU) baru dalam bidang HKI di awal 2000-an, sebagai respon akan tuntutan standar minimal HKI yang diminta oleh the Agreement on Trade-Related Aspects of Intellectual Property Rights (TRIPS) untuk dipenuhi oleh negara-negara anggota WTO.

Serangkaian UU HKI baru yang dikeluarkan oleh pemerintah Republik Indonesia di awal 2000-an tersebut bertujuan untuk mempersiapkan Indonesia dalam memasuki era perdagangan global sekaligus memacu semakin maraknya investasi asing di Indonesia. Negara-negara yang menjadi mitra dagang Indonesia serta para investor asing membutuhkan perlindungan hukum atas aset kekayaan intelektual yang dimilikinya untuk dapat melakukan kegiatan bisnis dengan pengusaha di Indonesia. Namun demikian, serangkaian UU HKI baru ini sebenarnya tidak hanya ditujukan untuk melindungi kekayaan intelektual dari pengusaha negara asing. Serangkaian UU HKI baru ini juga ditujukan untuk memberikan perlindungan hukum bagi kekayaan intelektual yang dimiliki oleh pengusaha lokal. Bahkan, lebih ideal lagi, UU HKI tersebut memberikan perlindungan tidak hanya kepada pengusaha lokal skala besar, tetapi juga kepada pengusaha lokal skala kecil dan menengah atau usaha kecil menengah (UKM).

Setelah dilegalisasi, pemerintah Indonesia melakukan sosialisasi untuk memperkenalkan serangkaian UU HKI baru ini serta manfaat perlindungan HKI bagi perekonomian di Indonesia. Salah satu yang menjadi target kegiatan sosialisasi tersebut adalah UKM yang banyak memiliki potensi kekayaan intelektual untuk dieksploitasi dan diberikan perlindungan. Akan tetapi, setelah satu dekade, UKM masih sedikit yang menggunakan HKI dalam kegiatan bisnisnya. Sebagai contoh, statistik menunjukkan aplikasi merek domestik hanya sejumlah 331,644 dari tahun 2001-2011. ${ }^{1}$ Jumlah ini yang sangat kecil bila dibandingkan dengan jumlah UKM di

\footnotetext{
${ }^{1}$ Direktorat Jenderal Hak Kekayaan Intelektual - Kementerian Hukum dan Hak Asasi Manusia Republik Indonesia, "Permohonan Pendaftaran Merek. Asing dan Domestik Tabun 2001 s.d. 2011”, http://www.dgip.go.id/ebscript/ publicportal.cgi?.ucid=376\&ctid=3\&type=0\&id=123, diakses tanggal 2 Agustus 2011 .
} 
Indonesia sebesar 4,6 juta. ${ }^{2}$ Dengan demikian dapat disimpulkan bahwa hanya sekitar kurang lebih 7,2 \% pengusaha UKM mendaftarkan mereknya.

Pembuatan batik merupakan salah satu industri yang sarat dengan potensi kekayaan intelektual yang dapat dieksploitasi dan dilindungi melalui berbagai cabang HKI. Namun demikian, tingkat pemanfaatan HKI di kalangan UKM industri ini juga masih rendah. Sebagai contoh, di Kota Pekalongan, sampai dengan Oktober 2013, hanya ada 170 UKM yang menerima sertifikat HKI sejak 2009. ${ }^{3}$ Walaupun tidak dijelaskan apakah 170 UKM tersebut bergerak di industri batik, tetapi dapat diasumsikan bahwa kebanyakan adalah UKM Batik karena industri pembuatan batik merupakan soko guru perekonomian rakyat di Pekalongan. ${ }^{4}$ Jumlah 170 UKM tersebut sangat rendah bila dibanding dengan jumlah UKM Batik di Kota Pekalongan sebanyak 643 UKM pada bulan Juli 2013. ${ }^{5}$ Sedangkan, Yogyakarta yang juga merupakan salah satu sentra batik di Indonesia baru mendaftarkan hak cipta dari 350 motif batik dari sekitar 500 motif batik yang dimiliki di daerah tersebut. ${ }^{6}$

\section{Rumusan Masalah}

Permasalahan dalam penelitian ini difokuskan pada faktor-faktor apakah yang menyebabkan tingkat pemanfaatan HKI di kalangan UKM Batik di Pekalongan dan Yogyakarta rendah?

\section{Tujuan Penelitian}

Penelitian ini bertujuan untuk mengetahui hal-hal yang menjadi penyebab rendahnya tingkat penggunaan HKI di kalangan pengusaha UKM Batik di Pekalongan dan Yogyakarta.

2 Afrizal Akbar, "Jumlah Pengusaha Indonesia Masih Rendah”, Kompas, 13 Februari 2010, http:// bisniskeuangan.kompas.com/read/2012/02/12/12450552/Jumlah.Pengusaha.Indonesia.Masih.Re-ndah, diakses tanggal 15 Mei 2011 .

${ }^{3}$ Isnawati, “1.000 Pelaku UKM Akan Difasilitasi Pengurusan HAKI”, Suara Merdeka, 2 Oktober 2013, http:/ Lwww.suaramerdeka.com/v1/index.php/read/news/2013/10/02/174250/1.000-Pelaku-UKM-Akan-DifasilitasiPengurusan-HAKI, diakses tanggal 12 September 2014.

${ }^{4}$ Kusnin Asa, Batik Pekalongan dalam Lintasan Sejarah, Paguyuban Pecinta Batik Pekalongan Dewan Koperasi Indonesia, Yogyakarta, 2006, hlm. 253.

${ }^{5}$ Siwi Nurbiajanti dan Neli Triana, "Dari Batik Pekalongan Mendunia", Kompas, 17 Juli 2013, http:// travel.kompas.com/read/2013/07/17/1758369/Dari.Batik.Pekalongan.Mendunia, diakses tanggal 13 September 2014.

6 “Sudah 350 Motif Batik Yogya Dipatenkan”, Republika Online, 24 Februari 2010, http://www.republika.co.id/ berita/breaking-news/seni-budaya/10/02/24/104735-sudah-350-motif-batik-yogya-yang-dipatenkan, diakses tanggal 13 September 2014. 


\section{Metode Penelitian}

Dilihat dari tujuannya, penelitian ini bersifat problem-identification dengan pendekatan empiris atau sosiologis. ${ }^{7}$ Data yang digunakan adalah data primer yang diperoleh melalui wawancara langsung dengan pihak terkait, seperti petugas dari Direktorat Jenderal Hak Kekayaan Intelektual (Ditjen HKI) dan pengusaha UKM Batik di Pekalongan dan Yogyakarta yang setiap daerah masing-masing diwakili oleh 7 orang pengusaha. Selain itu, penelitian ini juga menggunakan data sekunder yang terdiri dari bahan hukum primer (peraturan perundang-undangan Republik Indonesia terkait HKI), bahan hukum sekunder (hasil penelitian dan karya ilmiah terkait HKI) dan bahan hukum tersier (kamus dan ensiklopedia). Data tersebut, kemudian, dianalisis secara kualitatif.

Pemilihan industri batik sebagai studi kasus dalam penelitian ini dikarenakan dua alasan. Pertama, batik terkenal sebagai produk asli Indonesia di tingkat nasional dan internasional. ${ }^{8}$ Kedua, batik, sebagai karya seni, adalah salah satu objek perlindungan ekspresi budaya tradisional atau folklore yang sekarang menjadi isu hangat di kalangan negara berkembang anggota TRIPS. ${ }^{9}$ Sementara itu, Pekalongan dan Yogyakarta dipilih menjadi lokasi penelitian karena kedua daerah ini terkenal sebagai sentra produksi batik di Indonesia. Pembuatan batik merupakan bidang usaha penting di kedua daerah tersebut dan kebanyakan didominasi oleh UKM. Data 2008 menunjukkan industri batik skala kecil menengah di kabupaten Pekalongan berjumlah 3433 unit, mempekerjakan 66.122 orang, dengan nilai produksi total produksi Rp. 438.995.400.000. ${ }^{10}$ Sementara itu, industri batik termasuk dalam sektor manufaktur yang merupakan penyumbang tertinggi ke-empat, sebesar 13,06\% , bagi gross regional domestic product di propinsi Daerah Istimewa Yogyakarta (DIY) pada 2007.11

\footnotetext{
${ }^{7}$ Soerjono Soekanto, Pengantar Penelitian Hukum, Penerbit Universitas Indonesia (UI-Press), Cetakan ke-3, Jakarta, 1986, hlm. 50.

${ }^{8}$ Selvie Sinaga, "Utilisation of Intellectual Property Rights by Indonesian Small and Medium Enterprises: A Case Study of Challenges Facing the Batik and Jamu Industries", Disertasi, University of Wollongong, Wollongong, 2012, hlm. 234.

${ }^{9}$ UNCTAD-ICTSD, Resource Book on TRIPS and Development, Cambridge University Press, Cambridge, 2005, hlm. 399.

${ }^{10}$ Yusmar Ardhi Hidayat, "Efisiensi Kain Batik Cap", artikel dalam Jurnal Ekonomi Pembangunan, Vol. 13, No. 1, Juni 2012, hlm. 79 .

${ }^{11}$ Biro Pusat Statistik Daerah Istimewa Yogyakarta, Daerah Istimewa Yogyakarta Dalam Angka, Biro Pusat Statistik Daerah Istimewa Yogyakarta, Yogyakarta, 2008.
} 


\section{Hasil Penelitian dan Pembahasan}

\section{Relevansi Hak Kekayaan Intelektual dengan Industri Batik di Indonesia}

Beberapa cabang HKI sangat relevan bagi industri pembuatan batik. Berikut ini adalah pembahasan mengenai cabang-cabang HKI yang memiliki keterkaitan dengan industri pembuatan batik tersebut.

\section{Hak Cipta dan Perlindungan Ekspresi Budaya Tradisional}

Karya cipta batik dilindungi oleh UU No. 19 Tahun 2002 tentang Hak Cipta (UUHC) sebagai bentuk ciptaan tersendiri. ${ }^{12}$ Terdapat beberapa pasal yang terkait dengan perlindungan karya cipta batik dalam UU tersebut. Pasal 12 ayat (1) huruf i UUHC menyebutkan seni batik sebagai salah satu objek perlindungan hak cipta. Penjelasan pasal ini menyatakan bahwa seni batik diproteksi karena memiliki nilai artistik dalam motif, bentuk dan komposisi warnanya. Akan tetapi, pasal ini tidak hanya dimaksudkan untuk batik, karena penjelasan pasal ini juga menyebutkan kain tradisional Indonesia, seperti songket $t^{13}$ dan $i k a t^{14}$, sebagai objek perlindungan hak cipta dalam kategori yang sama dengan seni batik. Walaupun UUHC tidak menyatakan secara eksplisit, seni batik yang disebut dalam Pasal 12 ayat (1) huruf i merujuk secara spesifik pada seni batik versi modern. Tidak seperti versi tradisional, batik modern merupakan karya individual yang dapat memenuhi persyaratan orisinal ${ }^{15}$ untuk mendapat perlindungan hak cipta.

Sementara itu, untuk batik tradisional, UUHC menyediakan perlindungan dalam bentuk folklore atau ekspresi budaya tradisional. Untuk batik tradisional yang motifnya telah lama dikenal oleh umum dan penciptanya tidak diketahui hari ini, Pasal 10 ayat (2) UUHC mengatur kepemilikan motif-motif batik seperti ini akan berada di tangan negara. Lama perlindungan hak cipta untuk batik tradisional seperti ini diberikan tanpa batas waktu. ${ }^{16}$ Selain itu, untuk melindungi batik tradisional dan ekspresi budaya tradisional Indonesia lainnya dari klaim kepemilikan pihak asing, Pasal 10 ayat (3) meminta orang asing untuk memperoleh ijin dari lembaga

\footnotetext{
${ }^{12}$ Tim Lindsey, et al (editor), Hak Kekayaan Intelektual: Suatu Pengantar, Alumni, Bandung, 2003, hlm. 101.

${ }^{13}$ Songket adalah kain tradisional dari Sumatera Selatan yang dihiasi benang perak dan emas. Lihat Michael Hitchcock, Indonesian Textiles, British Museum Press, London, 1991, hlm. 40.

${ }^{14}$ Ikat adalah kain tradisional yang terkenal di wilayah timur kepulauan Flores, Sumba, Sabu, Rote, Lembata dan Maluku. Lihat, Ibid., hlm. 74.

${ }^{15}$ Pasal 1 ayat (3) UUHC.

${ }^{16}$ Pasal 31 ayat (1) huruf a UUHC.
} 
yang berwenang untuk mempublikasikan dan mereproduksi setiap ekspresi budaya tradisional yang disebut dalam Pasal 10 ayat (2) tersebut.

Jelas terlihat di sini pemerintah Indonesia memandang potensi penyalahgunaan materi ekspresi budaya tradisional datang kebanyakan dari luar negeri dan dari orang asing, seperti turis dan kolektor barang antik dari negara kaya. ${ }^{17}$ Akan tetapi, walaupun niat dari pemerintah ini positif posisi komunitas lokal sebagai pihak yang menghasilkan ekspresi budaya tradisional tidak begitu jelas, terutama mengenai bagaimana hasil eksploitasi dari materi ekspresi budaya tradisional tersebut dibagikan kepada mereka. ${ }^{18}$

Menurut Pasal 10 ayat (4) UUHC, hak cipta atas ekpresi budaya tradisional atau folklor yang dipegang oleh negara, sebagaimana dimaksudkan dalam Pasal 10 ayat (2), akan diatur lebih lanjut oleh Peraturan Pemerintah (PP). Namun, sampai saat ini PP yang dimaksud belum pernah dikeluarkan. Dalam kenyataannya, klaim atas batik dan beberapa folklor Indonesia sebagai warisan budaya Malaysia beberapa waktu lalu ${ }^{19}$ telah membuat pemerintah lokal lebih peduli terhadap aset budaya mereka, terutama motif batik, dan mempercepat tindakan pendaftaran hak cipta atas aset budaya tersebut. Sebagai contoh, pada 2008 pemerintah Solo telah mengajukan pendaftaran 415 motif batik kota tersebut. ${ }^{20}$ Walaupun ketiadaan PP tidak menghentikan inisiatif pemerintah daerah dalam melindungi materi folklor mereka, PP tersebut masih tetap dibutuhkan untuk lebih memberikan jaminan terhadap perlindungan ekspresi budaya tradisional Indonesia. Selain itu, PP tersebut diharapkan mengandung pasal-pasal yang memperjelas kedudukan komunitas lokal terhadap keuntungan dari eksploitasi materi folklor mereka.

Terkait dengan hak cipta, banyak UKM dalam industri batik yang tidak dapat menikmati perlindungan hak cipta menurut Pasal 12 ayat (1) huruf (i) untuk produk batik mereka. Walaupun pemilik UKM ini menciptakan motif batik baru secara aktif, sulit untuk motif baru tersebut untuk memenuhi kriteria persyaratan orisinal untuk perlindungan hak cipta. Kebanyakan dari motif ini mengandung banyak

\footnotetext{
${ }^{17}$ Christoph Antons, "What is “Traditional Cultural Expression”? International Definitions and Their Application in Developing Asia", artikel dalam The WIPO Journal: Analysis and Debate of Intellectual Property Issues, No. 1, 2009, hlm 103.

${ }^{18}$ Ibid., hlm.111. Lihat juga Chistoph Antons, Intellectual Property Law in Indonesia, Kluwer Law, Amsterdam, 2000, hlm. 87.

${ }^{19}$ Peter Gelling, "Score One for Indonesia in the War Over Batik”, New York Times, 14 September 2009, http:/ /www.nytimes.com/2009/09/15/world/asoa/15iht-batik.html? =1, diakses tanggal 20 Mei 2011.

20 "Pemkot Solo akan Patenkan 140 Motif Batik", Kompas, 19 Juni 2008, http:// nasional.kompas.com/read/ 2008/06/19/22081811/Pemkot.Solo.akan.Patenkan.140.Motif.Batik., diakses tanggal 23 Mei 2011.
} 
elemen motif batik yang telah lama dikenal secara umum di Jawa, seperti motif kawung dan semen. Pengusaha batik, terutama UKM, jarang membuat banyak variasi dari motif-motif tradisional tersebut. ${ }^{21}$ Di samping itu, pengusaha UKM tersebut telah terbiasa meniru motif batik yang diciptakan oleh pengrajin atau pengusaha dan menambahkan motif-motif tiruan tersebut untuk karya mereka sendiri. ${ }^{22}$ Dengan demikian, desain baru yang dipakai pada kain batik sering sulit memenuhi kriteria orisinal tersebut.

\section{Desain Industri}

Desain Industri merupakan cabang HKI lainnya yang terkait dengan industri batik. Berbeda dengan hak cipta yang melindungi ciptaan "seni murni", desain industri melindungi ciptaan "seni pakai". ${ }^{23}$ Beberapa elemen dari industri batik, yaitu diproduksi secara massal di pabrik, seperti batik cap dan printing, dan desain dari kain batik jenis tersebut, termasuk motif dan warna, sesuai dengan definisi dari desain industri dalam Pasal 1 ayat (1) UU No. 31 Tahun 2000 tentang Desain Industri (UUDI). ${ }^{24}$ Perlindungan desain industri diberikan melalui registrasi untuk waktu 10 tahun sejak tanggal masuknya aplikasi. ${ }^{25}$ Untuk dapat dilindungi oleh hak desain industri, suatu desain harus baru. ${ }^{26}$ Persyaratan baru disini sedikit berbeda dengan persyaratan orisinal yang diminta untuk mendapat perlindungan hak cipta. Walaupun banyak desain batik yang diproduksi saat ini mengandung motif tradisional, jika pencipta menambahkan elemen baru maka desain tersebut dapat dilindungi oleh desain industri.

Akan tetapi, secara praktis, hak desain industri sebagai perlindungan bagi usaha pembuatan batik dirasakan kurang bermanfaat. Berdasarkan pengalaman salah seorang pengusaha UKM batik, siklus waktu sebuah desain batik di pasaran biasanya hanya tiga bulan. ${ }^{27}$ Setelah waktu tiga bulan, kebanyakan desain batik tidak

${ }^{21}$ Wawancara dengan tujuh pengusaha UKM Batik di Pekalongan (Pekalongan, 21 Maret 2009) dan tujuh pengusaha UKM Batik di Yogyakarta (Yogyakarta, 25-27 Maret 2009).

${ }^{22}$ Ibid.

${ }^{23}$ Muhamad Djumhana \& R. Djubaedillah, Hak Milik Intelektual: Sejarah, Teori dan Prakteknya di Indonesia, Citra Aditya Bakti, Bandung, 2003, hlm. 221.

${ }^{24}$ Pasal 1 ayat (1) UUDI No. 31 Tahun 2000 tentang Desain Industri (UUDI) menyatakan "Desain Industri adalah suatu kreasi tentang bentuk, konfigurasi, atau komposisi garis atau warna, atau garis dan warna, atau gabungan daripadanya yang berbentuk tiga dimensi atau dua dimensi yang memberikan kesan estetis dan dapat diwujudkan dalam pola tiga dimensi atau dua dimensi serta dapat dipakai untuk menghasilkan suatu produk, barang, komoditas industry, atau kerajinan tangan."

${ }^{25}$ Pasal 5 ayat (1) UUDI

${ }^{26}$ Pasal 2 ayat (1) UUDI

${ }^{27}$ Wawancara dengan seorang pengusaha UKM batik di Pekalongan (Pekalongan, 21 Maret 2009). 
lagi terlalu menarik minat pembeli di pasaran, bahkan sudah tidak dipasarkan lagi. Dalam hal ini, perlindungan hak desain industri yang membutuhkan setidaknya empat atau lima bulan proses registrasi ${ }^{28}$, tidak lagi cocok untuk siklus pemasaran dalam suatu usaha batik. Oleh karena itu, banyak usaha batik, terutama UKM, yang tidak terlalu tertarik untuk mendapat perlindungan desain industri.

\section{Rahasia Dagang}

Informasi tentang teknik dan proses pewarnaan pembuatan batik, termasuk peralatan (seperti canting dan berbagai pelat cetakan motif) adalah subjek perlindungan rahasia dagang. ${ }^{29}$ Perlindungan rahasia dagang diberikan sepanjang informasi berharga tersebut masih dijaga kerahasiaannya oleh pemiliknya. Akan tetapi, informasi rahasia tersebut harus juga memiliki nilai ekonomis ${ }^{30}$ dan pemiliknya harus melakukan upaya untuk menjaga kerahasiaannya ${ }^{31}$. Sekali lagi, proses pembuatan batik dan peralatannya telah lama diketahui umum dan menjadi obyek penelitian populer dari berbagai ilmuwan internasional. Tidak seperti situasi sekarang, pada awal sejarah industri batik, HKI, termasuk rahasia dagang, bukanlah suatu isu bagi industri tersebut. Pada masa itu, pembuat batik senang berbagi pengetahuan mereka tentang semua aspek dari batik kepada setiap orang, termasuk orang asing, tanpa kekuatiran bahwa orang-orang ini akan meniru karya mereka. Walaupun masih banyak yang berpandangan sama seperti ini ${ }^{32}$, pembuat batik, termasuk UKM, lebih menyadari arti penting HKI bagi karya mereka saat ini.

\section{Merek}

Industri pembuatan batik tidak memiliki kendala yang berarti untuk dapat terlindungi oleh merek. Dalam kenyataannya, apapun ukuran dan bidangnya, setiap usaha memerlukan merek untuk memasarkan produk-produknya. Merek adalah suatu tanda untuk membedakan barang-barang atau jasa sejenis yang dihasilkan oleh pihak lain dalam suatu perdagangan. ${ }^{33}$ Selain itu, sebuah merek juga berfungsi

${ }^{28}$ Walaupun UUDI dan PP No. $1 / 2005$ tentang Pelaksanaan Undang-Undang No. 31/ 2000 tentang Desain Industri tidak menyebutkan minimal waktu proses registrasi desain industri, tetapi dapat disimpulkan dari kedua peraturan perundang-undangan tersebut seluruh proses pendaftaran desain industri yang tidak mendapat keberatan dari pihak lain adalah empat atau lima bulan.

${ }^{29}$ Pasal 2 ayat (1) UU No. 30 Tahun 2000 tentang Rahasia Dagang (UURD).

${ }^{30}$ Pasal 3 ayat (1) UURD

${ }^{31}$ Pasal 3 ayat (4) UURD

${ }^{32}$ Wawancara dengan tujuh UKM Batik di Pekalongan (Pekalongan, 21 Maret 2009) dan tujuh UKM Batik di Yogyakarta (Yogyakarta, 21-25 Maret 2009).

${ }^{33}$ O.K. Saidin, Aspek Hukum Hak Kekayaan Intelektual, PT Raja Grafindo Perkasa, Jakarta, 2004, hlm. 345. 
sebagai penjamin kualitas ${ }^{34}$ dari produk-produk yang disediakan oleh suatu usaha. Karena merek sangat berpengaruh terhadap proses marketing suatu produk, nilai suatu merek dapat melebihi aset total dari suatu bisnis. ${ }^{35}$

Merek yang terdaftar diproteksi untuk jangka waktu 10 tahun di Indonesia dan dapat diperbaharui. ${ }^{36}$ Saat ini terdapat beberapa merek terkenal di industri batik Indonesia, seperti Batik Keris dan Danar Hadi. Kedua merek tersebut dimiliki oleh usaha besar yang berpusat di Solo, tetapi memiliki banyak toko di berbagai kota besar di seluruh Indonesia. Tidak seperti usaha besar, banyak UKM di industri batik yang tidak melindungi merek mereka. Selain karena ketiadaan pengetahuan mengenai pentingnya merek untuk bisnis mereka, sejumlah besar UKM batik menyebutkan kompleksitas dari prosedur pendaftaran dan dan biayanya sebagai alasan mengapa mereka tidak mendaftarkan merek mereka. ${ }^{37}$

Selain alasan eksternal, menariknya, beberapa usaha batik kecil, terutama pada tingkat industri rumahan, walaupun tertarik memiliki dan mendaftarkan merek mereka, berpikir merek tidak cocok untuk usaha kecil mereka. Daripada menggunakan metode marketing modern yang membutuhkan merek untuk usaha mereka, usaha rumahan batik menjual karya mereka melalui pesanan langsung dari usaha menengah dan besar batik. Usaha menengah dan besar tersebut lalu menempelkan label merek mereka pada kain batik tersebut sebelum menjualnya di pasar. Sistem sub-kontrak ini telah biasa dipraktekkan dalam industri batik dan telah dikenal sejak abad ke-19 melalui Alapan atau konrak sistem yang biasanya dikontrol oleh pedagang perantara dari etnis Cina. ${ }^{38}$ Di bawah sistem ini, pedagang perantara menyediakan bahan baku kepada pembuat batik dan sebagai imbalannya mereka menerima kain batik yang telah jadi sesuai dengan nilai yang telah ditentukan dalam kontrak berdasarkan nilai tukar pada saat penyediaan bahan baku tersebut. ${ }^{39}$ Sekarang ini, pedagang perantara tidak lagi menyediakan bahan baku batik, tetapi mereka membayar seluruh harga grosir batik yang mereka pesan melalui sistem sub-kontrak ini. Untuk industri rumahan batik yang terlibat dalam sistem

\footnotetext{
${ }^{34}$ Ibid.

${ }^{35}$ World Intellectual Property Organization, "Why are Trademarks Relevant to the Success of Your SME", http://www.wipo.int/sme/en/ip_business/marks/tm_relevance.htm, diakses tanggal 25 Mei 2012.

${ }^{36}$ Pasal 28 UU No. 15 Tahun 2001 tentang Merek (UUM).

${ }^{37}$ Wawancara dengan tujuh UKM Batik di Pekalongan (Pekalongan, 21 Maret 2009) dan tujuh UKM Batik di Yogyakarta (Yogyakarta, 21-25 Maret 2009).

${ }^{38}$ Matsuo Hirashi, The Development of Javanese Cotton Industry, The Institute of Developing Economies, Tokyo, 1970, hlm. 82.

${ }^{39} \mathrm{Ibid}$.
} 
sub-kontrak ini, merek menjadi kehilangan daya tariknya sebagai penanda identitas dan penjamin kualitas suatu produk di pasar.

\section{Indikasi Geografis (IG)}

Perlindungan IG diatur dalam Pasal 56-59 UUM. Dalam Penjelasan Pasal 56 UUM dinyatakan bahwa perlindungan IG diberikan untuk barang-barang yang diproduksi oleh alam, pertanian, dan proses industri dan kerajinan tangan. Perlindungan IG sesuai untuk produk-produk dari industri batik, baik yang diproses dengan mesin, menggunakan pelat cetakan, atau ditulis tangan. Dalam kasus industri batik, perlindungan IG diperoleh melalui sistem pendaftaran. ${ }^{40}$ Orang yang membuat batik atau lembaga yang mewakili komunitas lokal yang memproduksi batik dapat mendaftarkan barang tersebut untuk memperoleh perlindungan IG. Perlindungan produk batik di bawah IG dapat mencegah tindakan penyalahgunaan oleh pihak asing karena standar dalam TRIPS menjamin perlindungan dari penggunaan IG yang menyesatkan publik sebagai asal geografis suatu barang ${ }^{41}$ dan menjadikannya sebagai tindakan persaingan curang ${ }^{42}$ di tingkat internasional. Namun, perlindungan IG di Indonesia, dimana registrasi masih diperlukan, mungkin memberatkan UKM di industri batik. Sama halnya dengan cabang HKI lainnya yang membutuhkan pendaftaran untuk mendapatkan perlindungan, birokrasi di Indonesia membuat proses pendaftaran IG rumit dan memakan waktu lama. Selain itu, kepemilikan hak IG, yang tidak dapat diberikan kepada individu, mungkin tidak terlalu berguna untuk UKM perorangan.

\section{Faktor-Faktor Penyebab Rendahnya Penggunaan HKI pada Kalangan UKM Batik di Pekalongan dan Yogyakarta}

Sebagaimana telah dibahas di atas, setiap cabang HKI yang relevan dengan industri batik memiliki tantangan tersendiri bagi pengusaha UKM untuk mendapatkan perlindungannya. Selain sulit memenuhi persyaratan khusus dari suatu cabang HKI untuk mendapat perlindungannya, industri batik, khususnya UKM, juga mengeluhkan beberapa hal lainnya. Berdasarkan wawancara yang dilakukan penulis terhadap 14 pengusaha UKM batik di Pekalongan dan Yogyakarta pada 2009, terdapat tiga hal yang menjadi penyebab keengganan dalam

\footnotetext{
${ }^{40}$ Pasal 56 ayat (2) UUM

${ }^{41}$ Pasal 22 ayat (2) (a) The Trade Related Aspects of Intellectual Property Rights (TRIPS).

${ }^{42}$ Pasal 22 ayat (2) (b) TRIPS.
} 
menggunakan HKI pada bisnis mereka, yaitu: (a) Prosedur pendaftaran yang panjang dan kompleks, (b) biaya registrasi yang mahal dan (c) lemahnya penegakan hukum bagi pelanggaran HKI. Bagian ini akan membahas lebih detail mengenai ketiga hal tersebut.

\section{Prosedur pendaftaran yang rumit dan lama}

Hampir semua cabang HKI yang relevan dengan industri batik tersebut di atas, kecuali hak cipta ${ }^{43}$ dan rahasia dagang, membutuhkan registrasi untuk mendapatkan perlindungannya. Prosedur pendaftaran HKI yang tercantum dalam UU Merek, UU Desain Industri dan UU Hak Cipta di Indonesia sebenarnya tidak banyak berbeda dengan negara lainnya. Akan tetapi, prosedur tersebut masih dirasakan rumit oleh UKM batik yang tidak berpengalaman dan kurang mendapat informasi akurat tentang sistem HKI.

Terkait dengan waktu, dalam UU Merek, waktu pendaftaran merek tersingkat tanpa adanya oposisi atau keberatan dari pihak ketiga adalah 14 bulan 10 hari $^{44}$ sebagaimana tertuang dalam Pasal 18 ayat (1) dan ayat (3); Pasal 22 ayat (1); dan Pasal 27 ayat (1) UU Merek RUU. Merek mengusulkan untuk memperpendek waktu pendaftaran ini menjadi 11 bulan dengan mengurangi waktu pemeriksaan substantif diperpendek menjadi enam bulan ${ }^{45}$ dari sembilan bulan ${ }^{46}$ yang ditentukan oleh UUM. Selain itu, RUU Merek juga mengusulkan untuk mengubah urutan pendaftaran merek menjadi pemeriksaan administratif diikuti publikasi dan pemeriksaan substantif. Urutan dalam UUM adalah pemeriksaan administratif diikuti langsung oleh pemeriksaan substantif dan publikasi. Perubahan urutan ini berpotensi mempercepat waktu pendaftaran karena tahap publikasi membuka kesempatan kepada pihak lain untuk mengajukan keberatan yang kemudian dapat menjadi pertimbangan penolakan atau penerimaan aplikasi tersebut. Selain itu, mendahulukan keberatan pihak lain terlebih dahulu berarti mengurangi beban Ditjen HKI untuk melakukan pemeriksaan substantif atas semua aplikasi merek yang masuk. Bagi pendaftar merek, terutama dari UKM, usulan prosedur baru ini

${ }^{43}$ Walaupun Pasal 35 ayat 4 UUHC menyatakan bahwa pendaftaran tidak wajib dan suatu karya tetap berhak atas perlindungan hak cipta di Indonesia, tetapi Pasal 35 ayat (1) UUHC menyatakan bahwa Ditjen HKI menerima pendaftaran karya cipta untuk keperluan pembuktian ketika ada sengketa.

${ }^{44}$ Akan tetapi, dalam kenyataannya, waktu minimal untuk memperoleh hak merek rata-rata dua tahun. Lihat Asnil Bambani Amri, "Banyak Calo di Pengurusan Hak Kekayaan Intelektual”, Kontan, 24 Oktober 2008, http:// kontan.realviewusa.com/default.aspx?iid=22518\&startpage=page0000036, diakses tanggal 25 Mei 2012.

${ }^{45}$ Pasal 22 RUU Merek.

${ }^{46}$ Pasal 18 ayat (3) UUM. 
akan menghemat waktu karena hasil dari tahap publikasi akan langsung memberikan jawaban atas aplikasi merek mereka. Sementara itu, sebagaimana disebutkan sebelumnya, pendaftaran hak cipta adalah tidak wajib ${ }^{47}$, tetapi lebih merupakan alat pembuktian bila terdapat sengketa di kemudian hari. ${ }^{48}$ Oleh karena itu, pendaftaran hak cipta lebih sederhana dibanding pendaftaran HKI lainnya karena tidak memerlukan pemeriksaan substantif. Karena lebih sederhana, waktu yang dibutuhkan untuk menyelesaikan pendaftaran hak cipta lebih singkat. Walaupun demikian, pendaftaran hak cipta tetap membutuhkan waktu sembilan bulan setelah tanggal memasukkan aplikasi. ${ }^{49}$ Bila dibandingkan dengan pendaftaran merek yang membutuhkan waktu 14 bulan 10 hari dengan adanya pemeriksaan substantif selama sembilan bulan, seharusnya pendaftaran hak cipta tanpa pemeriksaan substantif membutuhkan waktu hanya sekitar lima bulan atau kurang. Sebagai perbandingan waktu pendaftaran hak cipta di China dapat diselesaikan dalam 30 hari $^{50}$, sementara di India hanya dua atau tiga bulan ${ }^{51}$.

Beralih ke hak desain industri, walaupun UU No. 31 Tahun 2000 tentang Desain Industri (UUDI) tidak mencantumkan berapa lama waktu proses administrasi pendaftaran, tetapi dapat disimpulkan bahwa total waktu yang dibutuhkan adalah empat atau lima bulan. ${ }^{52}$ Waktu tersebut adalah total waktu tersingkat apabila tidak terdapat keberatan dari pihak lain. Singkatnya waktu pendaftaran ini dikarenakan pemeriksaan substantif dalam aplikasi hak desain industri hanya dibutuhkan apabila terdapat keberatan terhadap aplikasi tersebut. ${ }^{53}$ Bila tidak terdapat keberatan setelah masa publikasi ${ }^{54}$ berakhir, Ditjen HKI akan mengeluarkan sertifikat desain industri 30 hari sesudahnya..$^{55}$

Dapat dimengerti proses pendaftaran desain industri lebih sederhana dan singkat karena desain yang dipergunakan dalam suatu industri berubah sangat

${ }^{47}$ Pasal 35 ayat (4) UUHC.

${ }^{48}$ Pasal 35 ayat (1) UUHC.

${ }^{49}$ Pasal 37 ayat (3) UUHC.

${ }^{50}$ China IPR SME Helpdesk, "Copyright in China: Application Process”, http://www.china-iprhelpdesk.eu/ faqs.php., diakses tanggal 29 Agustus 2012.

${ }^{51}$ Copyright Office-Government of India, "Copyright: Frequently Asked Questions”, http://copyright.gov.in/ frmFAQ.aspx., diakses tanggal 20 Mei 2012.

${ }^{52}$ Dalam praktek, untuk memperoleh sertifikat desain industri dibutuhkan waktu dua atau tiga tahun. Lihat Zakaria, "Waktunya Lama, Enggan Mengurus HKI", Koran Tempo, 4 Oktober 2009, http://hukumham.info/ index.php?option=com content\&task=view\&id=3439\&Itemid=99999999., diakses tanggal 1 Juni 2012.

${ }^{53}$ Pasal 26 ayat (5) UUDI.

${ }^{54}$ Masa publikasi dalam proses pendaftaran hak desain industri adalah maksimal tiga bulan setelah tanggal penerimaan aplikasi pendaftaran. Lihat Pasal 25 ayat (1) UUDI.

${ }^{55}$ Pasal 29 ayat (1) UUDI 
cepat. Tanpa pemeriksaan substantif memang akan akan mengurangi waktu yang diperlukan untuk prosedur pendaftaran hak desain industri. Namun, hal ini juga mengurangi wewenang Ditjen HKI untuk melakukan pemeriksaan substantif sehingga berakibat berkurangnya kontrol terhadap pemenuhan syarat kebaruan (novelty) seperti yang dimaksud dalam Pasal 2 ayat (1) UUDI.

Sistem yang tidak mewajibkan pemeriksaan substantif membutuhkan partisipasi aktif dari masyarakat untuk mendaftarkan keberatan terhadap produk yang tidak pantas diberikan hak desain industri. ${ }^{56}$ Bila partisipasi masyarakat kurang dan ditambah lagi waktu publikasi dalam UUDI yang hanya maksimal tiga bulan ${ }^{57}$ dikuatirkan akan banyak hak desain industri diberikan tanpa pemeriksaan yang layak ${ }^{58}$ dan hal ini memperbesar potensi sengketa. Dari sudut pandang UKM, waktu pendaftaran hak desain industri yang lebih singkat adalah hal positif. Namun, jika waktu singkat ini tidak diseimbangkan dengan prosedur pemeriksaan layak yang mencegah sengketa di masa mendatang, hal ini pasti juga tidak efektif untuk UKM.

\section{Biaya Registrasi yang Mahal}

Biaya wajib untuk pendaftaran HKI ditentukan oleh pemerintah dan dimasukkan dalam suatu Peraturan Pemerintah (PP) yang diperbaharui secara rutin sesuai dengan keadaan di Indonesia. Untuk HKI yang ditangani oleh Ditjen HKI, seperti merek, hak cipta, paten, desain industri dan rahasia dagang, biaya pendaftaran berdasarkan PP No. 38 Tahun 2009 tentang Jenis dan Tarif atas Jenis Penerimaan Negara Bukan Pajak yang Berlaku pada Departemen Hukum dan Hak Asasi Manusia (HAM) yang berlaku mulai tanggal 4 Juni 2009. PP No. 38 Tahun 2009 adalah peraturan terakhir yang mengatur penerimaan negara yang diperoleh dari jasa-jasa yang disediakan oleh Kementerian Hukum dan HAM. PP ini mengandung daftar jenis dan tarif yang berlaku bagi orang-orang yang membutuhkan jasa dari Kementerian Hukum dan HAM. Salah satu penerimaan bukan pajak yang disebut dalam PP ini adalah semua yang terkait biaya untuk HKI, termasuk biaya pendaftaran HKI, biaya pemeliharaan paten dan merek, penerbitan sertifkat HKI, dan perubahan nama dan alamat dari pemegang HKI.

\footnotetext{
${ }^{56}$ Robinson Sinaga, "Sistem Pemberian Hak Desain Industri”, artikel dalam Media HKI, Vol II, No. 2, April 2005, hlm. 14.

${ }^{57}$ Pasal 25 ayat (1) UUDI.

${ }^{58}$ Sara Holder dan Lisa Yong, "Indonesia: Rethinking Indonesia”, http://www.managingip.com/Article/ 1321298/Supplements/Indonesia-Rethinking-Indonesia.html?supplementListId=58720, diakses tanggal 3 Juni 2012.
} 
Dari lampiran PP tersebut diketahui tentang total biaya wajib dikeluarkan untuk pendaftaran pertama kali merek adalah Rp. 700.000 dan hak cipta adalah Rp. 300.000. Untuk hak desain industri, pendaftar yang mengelola usaha kecil akan memperoleh biaya $40 \%$ lebih ringan dari pendaftar yang memiliki usaha menengah dan besar. Pemberian biaya lebih ringan ini adalah wujud pengakuan pemerintah Indonesia terhadap keberadaan UKM. Akan tetapi, sayangnya, kebijakan ini tidak berlaku untuk semua cabang HKI di Indonesia. Dalam PP tersebut, biaya lebih ringan untuk UKM hanya diberikan untuk cabang desain industri, desain tata letak sirkuit terpadu, rahasia dagang ${ }^{59}$ dan merek. Untuk hak merek, biaya lebih ringan ini diberikan bukan untuk pendaftar pertama, tetapi untuk pembaharuan merek setelah perlindungan 15 tahun pertama berakhir.

Kebijakan memberikan biaya lebih ringan kepada UKM untuk pendaftaran semua cabang HKI dapat merangsang penggunaan HKI dalam bisnis UKM di Indonesia. Tidak jelas mengapa pemerintah membatasi kebijakan biaya lebih ringan bagi UKM ini hanya untuk beberapa cabang HKI. Ketika hal tersebut ditanyakan kepada Ditjen HKI, petugas terkait ${ }^{60}$ hanya menjawab bahwa semua cabang HKI yang diberikan keistimewaan biaya pendaftaran lebih ringan untuk UKM adalah penting untuk UKM Indonesia. Jawaban ini tidak meyakinkan karena selain hak desain industri, rahasia dagang, desain tata letak sirkuit terpadu dan merek masih terdapat hak cipta dan paten sederhana yang juga relevan dan penting untuk UKM di Indonesia, tetapi tidak terkena kebijakan ini. Selain itu, dalam bidang merek, walaupun usaha kecil diberikan kebijakan biaya lebih ringan, hal ini tidak berlaku untuk pendaftaran merek pertama kali yang sebenarnya sangat dibutuhkan untuk mendorong minat UKM dalam mendaftarkan dan menggunakan merek dalam bisnis mereka.

Untuk UKM di industri batik, kebijakan biaya lebih ringan untuk pendaftaran cabang-cabang HKI yang relevan, seperti hak cipta, merek dan desain industri, sangat tepat untuk merangsang minat UKM mendaftarkan HKI terkait mereka. Namun cara pengaplikasian kebijakan tersebut dirasakan kurang tepat oleh UKM batik. Untuk memperoleh biaya pendaftaran lebih ringan tersebut, UKM yang bermaksud

\footnotetext{
${ }^{59}$ Rahasia dagang tidak membutuhkan pendaftaran, tetapi Pasal 8 ayat (2) UURD menyatakan semua urusan administrasi terkait dengan perjanjian lisensi dan pengalihan rahasia dagang kepada pihak lain harus dicatat oleh Ditjen HKI dengan membayar sejumlah biaya. Bila tidak dicatat, maka semua perjanjian lisensi dan pengalihan rahasia dagang tersebut tidak memiliki konsekuensi hukum untuk pihak ketiga.

${ }^{60}$ Wawancara dengan SY, petugas Ditjen HKI yang menangani program-program yang ditujukan untuk UKM, Tangerang, 21 Februari 2009.
} 
mendaftarkan cabang-cabang HKI terkait harus direkomendasikan oleh instansi pemerintah yang relevan dengan industri mereka. ${ }^{61}$ Instansi-instansi tersebut adalah Kementerian Industri, Kementerian Negara Koperasi dan UKM, Kementerian Perdagangan pada tingkat nasional dan Dinas Perdagangan dan Industri dan Dinas Koperasi dan UKM pada tingkat regional. Untuk mendapat rekomendasi dari instansi-instansi tersebut, biasanya UKM harus menjadi peserta program-program yang diadakan oleh instansi tersebut. ${ }^{62}$ Selain dana yang terbatas untuk program HKI terkait UKM, informasi tentang program bantuan tersebut juga mungkin tidak disampaikan secara merata. ${ }^{63}$ Oleh karena itu, hanya sebagian kecil UKM yang berpartisipasi dalam program-program bantuan tersebut dan mendapat rekomendasi untuk menikmati biaya pendaftaran lebih ringan bagi UKM sebagaimana tercantum dalam PP No. 38 Tahun 2009.

Selain biaya pendaftaran wajib, ternyata masih terdapat biaya dan pengeluaran tidak wajib, seperti biaya konsultan HKI yang harus dikeluarkan oleh seorang pendaftar HKI. Tidak seperti biaya wajib, tidak terdapat jumlah pasti atas biaya tersebut karena hal itu tergantung dari keadaan masing-masing pendaftar. Akan tetapi, kadang kala biaya tidak wajib ini melebihi biaya wajib yang ditentukan PP tersebut. Sebagai contoh, biaya normal untuk konsultasi dan pembuatan aplikasi pendaftaran yang dikenakan oleh seorang konsultan HKI berkisar antara Rp. 4.000.000,00 sampai Rp. 10.000.000,00. ${ }^{64}$ Walaupun tidak ada kewajiban untuk menggunakan jasa konsultan HKI, seorang pendaftar HKI yang tidak pengalaman dan kurang informasi akan mengalami kesulitan. Di samping itu, penggunaan jasa konsultan HKI dapat menghindari masalah hukum di kemudian hari. ${ }^{65}$

Dalam proses pendaftaran HKI, sudah menjadi rahasia umum terdapat calo yang dapat membantu berbagai proses administrasi terkait HKI, termasuk pendaftaran, di kantor Ditjen HKI. Calo meminta biaya jasa yang lebih rendah

${ }^{61}$ Ibid..

${ }^{62}$ Wawancara dengan SH, karyawan pada Dinas Perindustrian Propinsi Jawa Tengah Semarang, 5 Maret 2009, wawancara dengan pemilik KJ, usaha menengah batik. Pekalongan, 21 Maret 2009.

${ }^{63}$ Wawancara dengan pemilik KJ, usaha menengah batik, dan NC dan MR, pemilik usaha menengah batik, Pekalongan, 21 Maret 2009.

${ }^{64}$ Amri, Op. Cit., hlm. 36. Kelihatannya mahalnya biaya yang disebutkan disini terkait dengan aplikasi pendaftaran paten. Sumber lainnya melaporkan bahwa biaya konsultasi HKI untuk membantu pendaftaran merek lebih murah berkisar antara Rp. 900.000 sampai dengan Rp. 1.500.000. Lihat, Elvani Harifaningsih, "Kasus Merek Dominasi Perkara HKI", tersedia http://www.dgip.go.id/ebscript/publicportal.coi?.ucid=376\&ctid=23\&id=2173\&type=2, diakses tanggal 4 Juni 2012.

${ }^{65}$ Amri, Op. Cit., 34. 
dibandingkan konsultan $\mathrm{HKI}^{66}$ dengan pelayanan lebih cepat. ${ }^{67}$ Mereka menggunakan koneksi mereka di dalam kantor Ditjen HKI untuk mempercepat proses administrasi yang diminta oleh orang yang menggunakan jasa mereka. Keberadaan calo di sini adalah berdasarkan laporan di 2008. Tidak diketahui dengan pasti apakah masih ditemukan calo dalam proses pendaftaran HKI di Ditjen HKI di tahun ini.

Pada akhirnya biaya wajib yang dikombinasikan dengan biaya tidak wajib menjadi cukup mahal bagi UKM yang berniat mendaftarkan HKI-nya. Walaupun biaya tidak wajib bukan bagian yang harus dipenuhi dalam prosedur aplikasi HKI, tetapi dalam banyak hal, biaya-biaya tersebut adalah faktor penentu untuk melalui proses birokrasi HKI di Indonesia. ${ }^{68}$ Kebanyakan pemilik UKM dengan pendapatan rendah, biaya pendaftaran dan pengeluaran terkait pendaftaran HKI lainnya telah menghambat mereka untuk menggunakan HKI dalam usaha mereka. ${ }^{69}$

\section{Lemahnya Penegakan Hukum bagi Pelanggar HKI}

Sudah menjadi rahasia umum bahwa penegakan hukum di bidang HKI lemah. Selain itu, banyak penegak hukum, seperti polisi dan jaksa, memiliki sikap permisif terhadap pelanggaran HKI di Indonesia. Lemahnya penegakan hukum ini menyebabkan maraknya praktek-praktek korupsi di kalangan penegak hukum di Indonesia. Sebuah studi tentang pola-pola penyimpangan dalam kasus-kasus pidana HKI menemukan berbagai jenis korupsi yang dilakukan oleh petugas polisi ketika memproses kasus pidana HKI. Sebagai contoh, polisi menerima uang dari pelanggar HKI untuk membiarkan pelanggar menjalankan usaha ilegalnya secara bebas. ${ }^{70}$ Dalam kasus lain, polisi meminta uang dari pelanggar HKI yang tertangkap oleh mereka agar kasus tersebut tidak diproses lebih lanjut ke Kejaksaan. ${ }^{71}$ Selain itu, sebuah penelitian yang dilakukan sebuah LSM di 2007 menempatkan pengadilan sebagai institusi kedua terkorup di Indonesia setelah polisi. ${ }^{72}$

${ }^{66}$ Sebagai contoh, di tahun 2008, biaya jasa calo untuk memasukkan dan memeriksa formulir pendaftaran merek adalah sebesar Rp. 300.000, sementara biaya wajib resmi pendaftaran merek yang berlaku saat itu hanya Rp. 450.000. Lihat Ibid.

${ }^{67}$ Ibid.

68 "Melawan Kenakalan di Balik Pendaftaran Merek",Hukum Online, 2009, http://www.hukumonline.com/ berita/baca/hol22440/melawan-kenakalan-di-balik-pendaftaran-merek, diakses tanggal 4 Juni 2012.

${ }^{69}$ Wawancara dengan 10 UKM batik di Yogyakarta dan Pekalongan (Yogyakarta dan Pekalongan, Maret dan April 2009).

${ }^{70}$ Imam Soegianto, "Penyelidikan Tindak Pidana Bidang HKI dan Pola-Pola Penyimpangannya", Thesis, Universitas Indonesia, Jakarta, 2002, hlm. 154-158.

${ }^{71}$ Ibid., hlm. 164-169.

${ }^{72}$ Lilian Budianto , "Índonesia's Judicial System Rated the Worst in Asia: Survey”, The Jakarta Post, 15 September 2008, http://www.thejakartapost.com/news/2008/09/15/idonesia039s-judicial-system-rated-worst-asia-survey.html, diakses tanggal 10 Juni 2012. 
Semua hal tersebut di atas menciptakan citra negatif sistem pengadilan di Indonesia dan membuat banyak pemilik UKM enggan mencari keadilan melalui pengadilan ketika HKI mereka dilanggar. Dalam pandangan mereka, biaya perkara HKI di pengadilan, dalam hal uang, waktu dan energi, lebih besar dibandingkan dengan keuntungan yang diperoleh dari HKI. Hal ini membuat pemilik UKM lainnya di Indonesia merasa ragu menggunakan HKI karena mereka berpikir bahwa HKI yang relevan dengan usaha mereka tidak dapat diberlakukan secara efektif untuk memproteksi kepentingan usaha mereka.

Dalam industri batik, beberapa pengusaha UKM memiliki pendapat bahwa hak cipta dan hak desain industri,yang secara teori relevan dengan usaha mereka, tidak bekerja dengan baik. Hal ini dikarenakan budaya meniru adalah sesuatu hal biasa terjadi di industri batik. Bahkan, di Pekalongan, kegiatan tiru meniru ini telah terjadi di zaman kolonial Belanda dan bukan sesuatu hal yang negatif bagi mereka. ${ }^{73} \mathrm{Jika}$ suatu motif atau desain batik laku di pasaran, pedagang batik lain akan meniru dan memproduksi kain serupa dengan atau tanpa modifikasi lagi. Tidak hanya motif atau desain yang ditiru, label tandatangan dari van Zuylen, batik terkenal pada zaman Belanda, yang memiliki fungsi seperti merek juga ditiru di masa lampau. ${ }^{74}$ Pandangan seperti ini dan budaya tiru meniru semakin memperkuat keengganan pengusaha UKM batik menggunakan HKI untuk melindungi bisnis mereka.

\section{Penutup}

Dari pembahasan di atas dapat disimpulkan bahwa pengusaha UKM di Indonesia, terutama pada industri batik di Pekalongan dan Yogyakarta, menghadapi berbagai tantangan untuk menggunakan HKI pada usaha mereka. Pertama, persyaratan dari cabang-cabang HKI itu sendiri yang ternyata tidak selalu dapat mengakomodir keadaan khusus dari industri batik di Indonesia. Kedua, sistem administrasi HKI di Indonesia yang tidak akomodatif terhadap kebutuhan UKM batik di Indonesia. Ketiga, lemahnya penegakan hukum bagi pelanggar HKI. Di satu sisi, petugas penegak hukum dinilai permisif dalam memberantas pelanggaran HKI, tetapi di sisi lain, pengusaha UKM batik itu sendiri memiliki kebiasaan tiru meniru yang sudah mengakar.

\footnotetext{
${ }^{73}$ Fatchiyah A. Kadir, "Perkembangan Industri Batik Pekalongan dari Abad 19 Sampai Sekarang", makalah pada Seminar “Jejak Telusur dan Pengembangan Batik Pekalongan”, Pekalongan, 18-19 Maret 2005, hlm. 93-4.

${ }^{74}$ Ibid., hlm. 94.
} 


\section{Daftar Pustaka}

Antons, Christoph, "Intellectual Property Law in Indonesia", Kluwer Law, Amsterdam, 2000.

Antons, Christoph, "What is "Traditional Cultural Expression"? International Definitions and Their Application in Developing Asia", artikel dalam The WIPO Journal: Analysis and Debate of Intellectual Property Issues, No. 1, 2009.

Asa, Kusnin, Batik Pekalongan dalam Lintasan Sejarah, Paguyuban Pecinta Batik Pekalongan Dewan Koperasi Indonesia, Yogyakarta, 2006.

Biro Pusat Statistik Daerah Istimewa Yogyakarta, Daerah Istimewa Yogyakarta Dalam Angka, Biro Pusat Statistik Daerah Istimewa Yogyakarta, Yogyakarta, 2008.

Akbar, Afrizal, 13 Februari 2010, "Jumlah Pengusaha Indonesia Masih Rendah", tersedia di website http://bisniskeuangan.kompas.com/read/2012/02/12/ 12450552/Jumlah.Pengusaha.Indonesia.Masih.Rendah, diakses tanggal 15 Mei 2013.

Amri, Asnil Bambani, "Banyak Calo di Pengurusan Hak Kekayaan Intelektual”, Kontan, 24 Oktober 2008, http://kontan.realviewusa.com/ default.aspx?iid=22518\&startpage $=$ page0000036, diakses tanggal 25 Mei 2012.

Budianto, Lilian, "Índonesia's Judicial System Rated the Worst in Asia: Survey", The Jakarta Post, 15 September 200815 September 2008, http:// www.thejakartapost.com/news/2008/09/15/idonesia039s-judicial-systemrated-worst-asia-survey.html, diakases tanggal 10 Juni 2012.

China IPR SME Helpdesk, "Copyright in China: Application Process", http:// www.china-iprhelpdesk.eu/faqs.php., diakses tanggal 29 Agustus 2012.

Copyright Office-Government of India, "Copyright: Frequently Asked Questions", http://copyright.gov.in/frmFAQ.aspx., diakses tanggal 20 Mei 2012.

Direktorat Jenderal Hak Kekayaan Intelektual - Kementerian Hukum dan Hak Asasi Manusia Republik Indonesia, "Permohonan Pendaftaran Merek Asing dan Domestik Tahun 2001 s.d. 2011", http://www.dgip.go.id/ebscript/ publicportal.cgi?.ucid $=376 \&$ ctid $=3 \&$ type $=0 \& i d=123$, diakses tanggal 2 Agustus 2011.

Djumhana, Muhamad \& R. Djubaedillah, Hak Milik Intelektual: Sejarah, Teori dan Prakteknya di Indonesia, Citra Aditya Bakti, Bandung, 2003.

Gelling, Peter, "Score One for Indonesia in the War Over Batik", New York Times, 14 September 2009, http://www.nytimes.com/2009/09/15/world/asoa/ 15iht-batik.html? =1, diakses tanggal 20 Mei 2011.

Harifaningsih, Elvani, "Kasus Merek Dominasi Perkara HKI", tersedia http:// www.dgip.go.id/ebscript/publicportal.cgi?.ucid $=376 \&$ ctid $=23 \& i d=$ 2173\&type $=2$, diakses tanggal 4 Juni 2012. 
Hidayat, Yusmar Ardhi, "Efisiensi Kain Batik Cap", artikel dalam Jurnal Ekonomi Pembangunan, Vol. 13, No. 1, Juni 2012.

Hirashi, Matsuo, The Development of Javanese Cotton Industry, The Institute of Developing Economies, Tokyo, 1970.

Hitchcock, Michael, Indonesian Textiles, British Museum Press, London, 1991.

Holder, Sara dan Lisa Yong, "Indonesia: Rethinking Indonesia", http:// www.managingip.com/Article/1321298/Supplements/Indonesia-RethinkingIndonesia.html?supplementListId=58720, diakses tanggal 3 Juni 2012.

Isnawati, “1.000 Pelaku UKM akan Difasilitasi Pengurusan HAKI”, Suara Merdeka, 2 Oktober 2013, http://www.suaramerdeka.com/v1/index.php/read/ news/2013/10/02/174250/1.000-Pelaku-UKM-Akan-DifasilitasiPengurusan-HAKI, diakses tanggal 12 September 2014.

Kadir, Fatchiyah A., "Perkembangan Industri Batik Pekalongan dari Abad 19Sampai Sekarang", makalah pada Seminar Jejak Telusur dan Pengembangan Batik Pekalongan, Pekalongan, 18-19 Maret 2005.

Tim Lindsey, et al (editor), Hak Kekayaan Intelektual: Suatu Pengantar, Alumni, Bandung, 2003.

“Melawan Kenakalan di Balik Pendaftaran Merek",Hukum Online, 2009, http:// www.hukumonline.com/berita/baca/hol22440/melawan-kenakalan-dibalik-pendaftaran-merek, diakses tanggal 4 Juni 2012.

Nurbiajanti, Siwi dan Neli Triana, "Dari Batik Pekalongan Mendunia", Kompas, 17 Juli 2013, http://travel.kompas.com/read/2013/07/17/1758369/ Dari.Batik.Pekalongan.Mendunia, diakses tanggal 13 September 2014.

"Pemkot Solo akan Patenkan 140 Motif Batik", Kompas, 19 Juni 2008, http:// nasional.kompas.com/read/2008/06/19/22081811/ Pemkot.Solo.akan.Patenkan.140.Motif.Batik., diakses tanggal 23 Mei 2011.

Saidin, O.K., Aspek Hukum Hak Kekayaan Intelektual, PT Raja Grafindo Perkasa, Jakarta, 2004.

Sinaga, Robinson,"Sistem Pemberian Hak Desain Industri", artikel dalam Media HKI, Vol II, No. 2, April 2005.

Sinaga, Selvie,"Utilisation of Intellectual Property Rights by Indonesian Small and Medium Enterprises: A Case Study of Challenges Facing the Batik and Jamu Industries", Disertasi, University of Wollongong, Wollongong, 2012.

Soegeng Sarjadi Syndicate dan Konrad Adenauer Stiftung, Kabupaten Pekalongan, http://www.cps-sss.org/web/home/kabupaten/kab/ Kabupaten+Pekalongan, diakses tanggal 12 Mei 2013.

Soegianto, Imam, "Penyelidikan Tindak Pidana Bidang HKI dan Pola-Pola Penyimpangannya", Thesis, Universitas Indonesia, Jakarta, 2002.

Soekanto, Soerjono, Pengantar Penelitian Hukum, Penerbit Universitas Indonesia (UIPress), Cetakan ke-3, Jakarta, 1986. 
"Sudah 350 Motif Batik Yogya Dipatenkan", Republika Online, 24 Februari 2010, http://www.republika.co.id/berita/breaking-news/seni-budaya/10/02/ 24/104735-sudah-350-motif-batik-yogya-yang-dipatenkan, diakses tanggal 13 September 2014.

UNCTAD-ICTSD, Resource Book on TRIPS and Development, Cambridge University Press, Cambridge, 2005.

World Intellectual Property Organization, "Why are Trademarks Relevant to the Success of Your SME", http://www.wipo.int/sme/en/ip_business/ marks/tm_relevance.htm, diakses tanggal 25 Mei 2012.

Zakaria, “Waktunya Lama, Enggan Mengurus HKI”, Koran Tempo, 4 Oktober 2009, http://hukumham.info/index.php?option=com_content\&task=view\&id= 3439\&Itemid=99999999, diakses tanggal 1 Juni 2012.

PP No. 1 Tahun 2005 tentang Pelaksanaan Undang-Undang No. 31/ 2000 tentang Desain Industri.

PP No. 38 Tahun 2009 tentang Jenis dan Tarif atas Jenis Penerimaan Negara Bukan Pajak yang Berlaku pada Departemen Hukum dan Hak Asasi Manusia (HAM).

UU No. 30 Tahun 2000 tentang Rahasia Dagang

UU No. 31 Tahun 2000 tentang Desain Industri.

UU No. 15 Tahun 2001 tentang Merek.

UU No. 19 Tahun 2002 tentang Hak Cipta. 